\title{
A SYNTACTICAL NOTE (GENESIS 3:15): IS THE WOMAN'S SEED SINGULAR OR PLURAL?
}

\author{
Jack Collins
}

\section{Summary}

This article addresses the question whether the woman's 'seed' in Genesis 3:15 is an individual (as LXX interprets) or her posterity, by an empirical study of how Biblical Hebrew used its pronouns and verb inflections when they are associated with zera', 'seed', when it has the nuance 'offspring'. Syntactically Genesis 3:15 exhibits the pattern found when zera' refers to an individual. The article concludes with some suggestions for following the exegetical consequences of this syntactical result.

\section{Introduction}

wĕ’êbâ ’āšît bênĕkā ûbên hāiššâ

ûbên zar`ăkāâ ûbên zar`āh

$h \hat{u}^{\supset}$ yěšupěkā rō’̌

wĕ’attâ těšûpennû ‘āqēb

And enmity shall I set between you and the woman, and between your seed and her seed;

he, he (?) will bruise you on the head, and you, you will bruise him (?) on the heel.

It has been customary for some time now to state that the woman's seed in Genesis 3:15 refers to her posterity in general; and that the 'crushing' or 'bruising'1 of the snake's head is

\footnotetext{
${ }^{1}$ For the purpose of this article I am following Franz Delitzsch, $A$ new commentary on Genesis (ET; Edinburgh: T. \& T. Clark, 1888), 161-62 (cf. F. Brown, S.R. Driver, C.A. Briggs, A Hebrew and English lexicon of the Old
} 
represented as being done through humanity in general. That is to say, the word zera' ('seed') is taken as a collective, and the pronoun $h \hat{u}^{\prime}$ is masculine singular in order to match its antecedent ( $z a r{ }^{\varsigma} \bar{a} h$, 'her seed'), and is better rendered 'it' or even 'they' (so too the suffix on těsûpennû, 'you will bruise him/ it/them'). 2

Authors who find a Messianic promise in this verse do not usually dissent from this grammatical analysis. They tend to see the Messiah as the representative or crystallisation of the woman's seed/posterity. ${ }^{3}$

Some have pointed to the LXX rendering, where Greek $\sigma \pi \varepsilon \dot{\rho} \mu \alpha$ ('seed', neuter) renders Hebrew zera', and $\alpha$ vi $\tau$ 's ('he',

Testament [Oxford: Oxford UP, 1906], 1003a), in taking both instances of $\check{s a p}$ to mean 'to bruise', as he puts it, 'the first time by trampling, the second by biting' (i.e., the sense is the same, but the referent is different, as seen in the different locations of the bruising).

${ }^{2}$ Compare R.A. Martin, 'The earliest Messianic interpretation of Genesis 3:15', JBL 84 (1965), 425-27, at 425: 'The use of the masculine pronoun [he] in English is indefensible as a translation of the Hebrew... Grammatically [zera'] is masculine, but actually it is a collective noun of which the natural gender is neuter. The proper translation in English of [ $\left.h \hat{u}^{\prime}\right]$ would be either "it" or "they" (meaning "the descendants of Eve").' Such standard reference works as Entsiqlopedya Miqra'it II:943-44, and Baumgartner's Hebräisches und aramäisches Lexikon zum AT I:271b, assume this to be so but have no discussion, and hence are not discussed here.

3From a traditional Protestant perspective, compare J. Calvin, Commentaries on the First Book of Moses, vol. 1 (ET 1847; repr. Grand Rapids: Baker, 1979), 170-71; Delitzsch, Genesis, 163-65; E. Hengstenberg, Christology of the Old Testament (ET 1847; abridged version, Grand Rapids: Kregel, 1970), 21-24; M.H. Woudstra, 'Recent translations of Genesis 3:15', CTJ 6 (1971), 194-203, at 199; G. van Groningen, Messianic revelation in the Old Testament (Grand Rapids: Baker, 1990), 113-14, and T.D. Alexander, 'Messianic ideology in the book of Genesis', in P.E. Satterthwaite, R.S. Hess, G.J. Wenham (eds.), The Lord's Anointed: Interpretation of Old Testament Messianic Texts (Carlisle/Grand Rapids: Paternoster/Baker, 1995), 19-39, at 30-31. G.J. Wenham, Genesis 1-15 (Waco: Word, 1987), 8081, appeals to a sensus plenior; he is hesitant to suppose the author of Genesis thought of a Messiah. From a different perspective W. Wifall, 'Gen 3:15 - A protevangelium?', $C B Q 36$ (1974), 361-65, argues that 'Gen 3:15 owes its present form to the Yahwist's adaptation of both the David story (2 Sam-1 Kgs 2) and ancient Near Eastern royal mythology to Israel's covenant faith and history. The Yahwist has thus presented Israel's history and pre-history within a "Davidic" or "messianic" framework.' 
masculine) renders Hebrew h $\hat{u}^{2}$. The mismatch in gender between pronoun and antecedent is held to be evidence that the LXX translator saw this as a prophecy of a specific individual. ${ }^{4}$ While this is generally acknowledged, many feel that the LXX is an interpretation that the Hebrew itself does not support, since the Hebrew is considered to support only a collective understanding of zerac and $h \hat{u}^{\supset} .5$

The purpose of this note is to raise the following questions about the LXX 'interpretation': is this what the Greek translator meant? And if so, did it have any basis in Hebrew usage, or is it a pure interpretation? None of the discussions of which I am aware are actually based on an empirical study of how the Hebrew language uses its pronouns and verb inflections when they are associated with zera', in those cases where this word has the nuance 'offspring'. ${ }^{6}$ The specific

${ }^{4}$ Compare D. Kidner, Genesis (Leicester: IVP, 1967), 71; V.P. Hamilton, Genesis 1-17 (Grand Rapids: Eerdmans, 1990) 199; drawing on Martin, "The earliest Messianic interpretation', 427, who declares the LXX to be 'the earliest evidence of an individual messianic interpretation' (but they do not share Martin's doubt that this is the correct understanding of the Hebrew text). As Alexander, 'Messianic ideology', 27 n. 21, notes, Targum Neofiti also puts a Messianic spin on this verse; but it does not represent this text as specifically the promise of an individual.

5In addition to Martin as cited above, compare H.P. Rüger, 'On some versions of Genesis 3.15, ancient and modern', BT 27 (1976), 105-10 (passim). C. Westermann, Genesis 1-11, (ET; Minneapolis: Augsburg, 1984), 259-61, emphatically denies any possibility of Messianic promise or protevangelium here, first because he takes zera' as collective, and second, because the context is that of a pronouncement of punishment, and 'it is not possible that such a form has either promise or prophecy as its primary or even secondary meaning' (p. 260). J. Barr, The Garden of Eden and the hope of immortality (Minneapolis: Augsburg Fortress, 1992) 140 n.28, calls this a 'crushing rebuttal of all such suggestions'. Interestingly this scholarly consensus is not reflected in some of the more common English versions, such as NRSV, CEV, NIV, and NJB (which has a footnote, 'Gk reads "he", suggesting a personal saviour').

${ }^{6}$ The bibliography here is not by any means exhaustive, but seems to be representative (since it draws on the three most recent comprehensive commentaries on the Hebrew, namely Westermann, Wenham, and Hamilton, and their bibliographies). P. Joüon and T. Muraoka, A grammar of Biblical Hebrew (Subsidia Biblica 14/I, II; Rome: Pontifical Biblical Institute, 1993) §149a, simply mentions that 'a pronoun which refers to a collective... can be in the plural', giving Gn. 15:13 as an example (with 
question here arises from the fact that the word zera' in Genesis 3:15 is the antecedent of a singular pronoun, $h \hat{u}^{2}$, which is the subject of a singular verb, yěsûpěkā ('he will bruise you'); and the antecedent of the singular pronominal suffix on těšupennû ('you will bruise him'). Can we observe any distinctive patterns in the pronouns and verb inflections, depending on whether $z^{2}{ }^{c}{ }^{c}$ refers to offspring in general or to a particular offspring?

The procedure of this study is fairly simple. Using the lexical entry of Brown-Driver-Briggs, I examined every case of zera' ' where it means 'offspring', noting where possible the behaviour of verb inflections, adjectives, and pronouns that are syntactically connected with the word zerac.7

\section{Tabulation of Results}

When zera' serves as a collective for 'offspring in general, posterity', it commonly has a singular verb inflection. Genesis 13:16 will serve as an example: gam-zar ‘ăkā yimmāneh ('your seed [posterity] also will be numbered'). Compare Genesis 15:5, 13a; $16: 10 ; 21: 12 ; 22: 17 ; 24: 60 ; 28: 14 ; 32: 12$ [MT 13]; 48:19; Numbers 14:24; Isaiah 14:20; 48:19a; 54:3; 61:9a; 66:22; Jeremiah 49:10; Psalm 22:30 [MT 31]; 25:13; 37:28; 89:36 [MT 37]; 102:28 [MT 29]; 112:2; Proverbs 11:21.

A number of times when zera ${ }^{c}$ is collective for 'posterity' it takes a plural verb inflection. For example, see Exodus 32:13: 'ettēn lězar'ăkem wĕnāhălû lĕ ōlām ('and I will give [it] to your seed [posterity] and they will inherit [it] forever').

zera' as posterity; see below). No comments to the point appear in the commentaries of U. Cassuto or N.H. Sarna or in the grammar of Waltke and O'Connor or in J. Levi's Die Inkongruenz im Biblischen Hebräisch (Wiesbaden: Harrassowitz, 1987).

${ }^{7}$ This is entry 4, $B D B, 282 \mathrm{~b}$; I have included their entry 5 ('seed as marked by moral quality') since in some cases the reference may well be to offspring, and because this category seems to be a ramification from the 'offspring' category. One verse, Je. 2:21, is improperly included in their entry 5; it is part of a metaphor that makes use of the basic 'physical' sense of 'seed' (entry 2). I have also limited this study to those cases where the word zera' controls the grammatical number of associated words (e.g., 'you and your seed' with plurals would not be a useful datum). The list here is intended to be exhaustive of such cases. 
Compare also Genesis 15:13b-14 (three verbs: wa‘ăbãdûm... ya‘ăbōdû... yẹșĕ’û, 'they will serve them... they will serve... they will go out');8 Isaiah 44:3-4;9 45:19, 25; Jeremiah 23:8; 31:36, 37; Psalm 22:23 [MT 24]; 69:36 [MT 37]; 105:6 (=1 Ch. 16:13); 2 Chronicles 20:7-8; Ezra 9:2; Nehemiah 9:2.10

A few examples of collective 'posterity' appear with adjectives (including participles); all are singular: Psalm 37:25 (this need not be more than a single descendant); 112:2; Job $5: 25 ; 21: 8$.

When zera' denotes 'posterity' the pronouns (independent pronouns, object pronouns, and suffixes) are always plural.11 For example, Genesis 17:9: 'attâ wĕzar'ăkā 'aḥăreykā lědōrōtām ('you and your seed after you, by their generations'). Compare Genesis 15:13 (lāhem... 'ōtām); 17:7-10;

${ }^{8}$ Compare v. 16 dôr yāšûbû ('a generation will return'). It would be interesting to examine how other collective nouns behave (especially those whose referent could be either singular or plural), such as those found in Joüon-Muraoka, $\S \S 135 b-c$.

${ }^{9}$ The fact that the plural șe ășă’eykã ('your descendants') appears in v. 3 probably affects the number of weșämẹhâ ('and they will sprout') in v. 4 .

${ }^{10}$ There does not seem to be any clear pattern as to whether a singular or plural verb is used; compare Joüon-Muraoka, §150e.

${ }^{11} \mathrm{An}$ apparent exception to this pattern is Is. 41:8 wě̉attâ yiśrā’ēel cabdîn ya ăqōb 'ăšer běhhartîkā zera' 'abrāhām 'ōhăbî ('and you [are] Israel my servant, Jacob whom I chose, seed of Abraham who loved me'). This is not a true exception: the address to Israel/Jacob is singular because in the fancy of the author the patriarch is ideally present. Thus the 'seed of Abraham' is the man Jacob; but this is a highly artistic context and can be used as evidence only with great reserve. The case of šĕmô in Is. 48:19, wayěhî kahôol

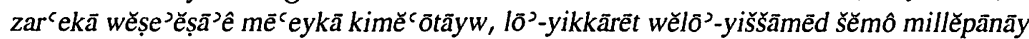
('and your seed would have been like the sand and the descendants of your loins like its grains, his/its name would not be cut off and not be destroyed from before me') is more difficult: the suffix could refer to $z^{\prime}{ }^{\prime} e k a \bar{~}$ ('your seed') though this seems harsh in view of the intervening plural wẹse’e’șā'ế; it could as easily refer to Jacob, since in v. 9 we have lěbiltî hakrîtekā ('in order not to cut you off') spoken to [the house of] Jacob (the referent of the second masculine singular pronouns from v. 4 on). The Greek tò ővoud́ $\sigma o v$ ('your name') suggests either a different text or an interpretative move of the translator that reflects this latter analysis. The preservation of the seed of Jacob would preserve the name of Jacob/Israel. 
48:11-12;12 Exodus 30:21; Leviticus 21:17; Deuteronomy 10:15;13 2 Kings 17:20; Isaiah 61:9b (hēm zera' berak yhwh, 'they are the seed the LORD has blessed'); 65:23; Jeremiah 23:8; 30:10 (=46:27); 33:26; Ezekiel 20:5; Psalm 106:27; Ezra 2:59 (=Ne. $7: 61) .14$

Not surprisingly, when zerac denotes a specific descendant, it appears with singular verb inflections, adjectives, and pronouns: e.g., for an adjective, Genesis 4:25 zera' 'aher ('another seed'); for pronouns (and verb inflections),

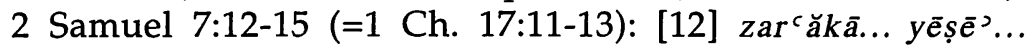
mamlaktô [13] hû́ 'yibneh... mamlaktô [14] lô... wěhû̉ yihyeh... ('[12] your seed... he will come out...his kingdom [13] he will build... his kingdom... [14] to him... and he will be', etc.). Compare also Genesis 21:13 (pronoun); 38:9a (verb); 1 Samuel 1:11 (pronouns); Isaiah 41:8 (pronoun).

The pattern for the Greek translations of these passages is identical (at least in the Pentateuch and Former Prophets, where the translation is generally of higher quality, and to the extent it is possible to see a distinction). More to the point, when the 'seed' is an individual, the pronoun will be masculine (or at least, not clearly neuter ${ }^{15}$ ), even though the Greek word $\sigma \pi \varepsilon \dot{\rho} \mu \alpha$ is neuter. Some very clear examples are 1 Samuel 1:11, where $\alpha$ v่ óv ('him') refers back to ( $\sigma \pi \varepsilon \dot{\varepsilon} \mu \alpha \dot{\alpha} v \delta \rho \hat{\omega} v)$ 'seed of men'; and 2 Samuel 7:12-14, where masculine pronouns (ö $\varsigma$,

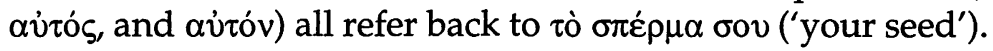

\footnotetext{
12But 'ôtām could be for 'his sons' (vv. 8-10).

${ }^{13}$ Contrast the singular suffix on 'ăboteyka ('your fathers') with the plural suffix in bākem which is in apposition to bězar'ãm ('their seed, namely you all'); both second person suffixes have the same referent (the audience); hence this is especially informative for the grammar of zera' (perhaps it overrides the second singular inflections?). This marks the shift from second person singular inflections (vv. 12-15a) to plural (vv. 15b-19); v. 20 returns to singular.

${ }^{14}$ But hēm ('they') could refer also to bêt 'ăbotâm ('their families').

${ }^{15}$ Ambiguity arises from the fact that in some cases the masculine and neuter forms of the pronoun are identical: e.g., we cannot tell whether a

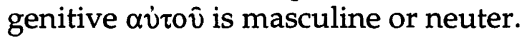




\section{Conclusions for Genesis 3:15}

The data documented above are widely distributed, consistent, and sufficiently attested to allow meaningful generalisations. The clearest syntactic parallel to our verse is 2 Samuel 7:13, which is a promise to David of an offspring (zerac, v. 12): hû ${ }^{2}$ yibneh-bayit lišĕî ('he will build a house for my name'). From these data it becomes clear that, on the syntactical level, the singular pronoun hû in Genesis 3:15 is quite consistent with the pattern where a single individual is in view. In fact, since the subject pronouns are not normally necessary for the meaning, we might wonder if the singular hâ $\hat{u}^{\prime}$ in Genesis 3:15 is used precisely in order to make it plain that an individual is being promised, 16 who will win a victory over the snake at cost to himself. 17 The evidence of the Greek translators makes it beyond question that the translator of Genesis 3:15 meant to convey that an individual was promised; this study indicates that his interpretation is consistent with Hebrew syntax elsewhere in the Bible. ${ }^{18}$

It should be admitted, however, that at this point we have used the data at the syntactical level, which is a fairly low level of integration. The move up to the exegetical level, to

${ }^{16}$ This is not contrary to Joüon-Muraoka, §146a, which sees the pronouns here as expressive of 'adversative juxtaposition': the question still remains, which parties are contrasted?

17This renders unnecessary the notion of Wenham, Genesis 1-15, 80 (cf. Alexander, 'Messianic ideology', 30), that the use of the imperfects of sûp convey the idea of unending conflict: the imperfect here is a simple future, which may or may not be an enduring state (see Joüon-Muraoka, §113b). The notion of P.P. Saydon, 'The conative imperfect in Hebrew', VT 12 (1962), 124-26, at 126, that the first imperfect is simple future ('he will attack you'), while the second is conative ('you will try to attack him') is also unnecessary (at least we can hardly agree with the assertion that 'a conative meaning must be attributed'; besides, all his other examples are wayyiqtol, which is not connected to the imperfect). The exegesis of Delitzsch, Genesis, 162-63, seems adequate for the text.

18It would be helpful to have a further study to relate this feature to the larger context of how nouns that can designate both individuals and collectives use pronouns, e.g., in Gn. 1:25 hayyat-hā’āreș lĕmînāh is perhaps 'the animal(s) of the land (each) by its kind', i.e., the singular pronoun is individualising ( $c f$. vv. 11-12, 24-25, and contrast v. 21, where the plural suffix refers to more than one category). 
answer the question whether this is what one finds in Genesis 3:15, will depend on one's view of other factors, such as how one's overall perception of the context should interact with the particulars; ${ }^{19}$ whether the interpretation should be based on the final form of the text or on reconstructed sources; what range of ideological messages one is willing to ascribe to the work; and so on. To treat adequately any of these questions is outside the scope of this modest syntactical note.

If, however, one grants for the sake of discussion that it is a valid approach to make a 'bottom-up' reading of the final form of this text, which has a relationship to the larger picture of Genesis, ${ }^{20}$ then it would be fair to read this as God's threat to the snake, of an individual who will engage the snake in combat and win. 21

${ }^{19}$ For example, if one takes this passage as an aetiology for the relations of snakes and humans, then of course one expects to read of humans in general; and if one takes a 'top-down' approach then this expectation will govern interpretation of the particulars. A 'bottom-up' approach, on the other hand, will refine and perhaps refute the expectation, or even the genre identification, on the basis of the particulars.

${ }^{20}$ For the argument that $\mathrm{Gn} .3$ is a coherent discourse with its climax at vv. 14-19, which has a relation to "the "spread of sin" theme in the macrostructure of Genesis 1-11', compare S. Kempf, 'Genesis 3:14-19: Climax of the discourse?', JOTT 6 (1993), 354-77 (quote from page 375), which interacts with, and in places corrects, R.W.L. Moberly, 'Did the serpent get it right?', JTS 39 (1988), 1-27 (who also attempts a close study of the current form of the text as a coherent whole). Neither article discusses the matters treated here.

${ }^{21}$ Note that whereas v. 15a speaks of the snake's seed and the woman's seed, in v. $15 \mathrm{~b}$ it is 'he' (hû́ ', i.e., the woman's 'seed') who will bruise 'you' (singular, i.e., the snake). Delitzsch, Genesis, 149-52 (on Gn. 3:1), argues that as a matter of authorial intent (intelligible to capable readers) 'an animal is intended, but an animal not speaking of its own accord, but as made the instrument of itself by the evil principle... The narrator confines himself to the external appearance of what took place, without lifting the veil from the reality behind it.' Additionally, consider the following factors: (1) the snake's wording of v. 4 reflects knowledge of 2:17 (the snake, not the woman, has introduced 'surely', i.e., the infinitive absolute, into this conversation); (2) animals do not have faculty of speech in Bible, hence there is some intervention here ( $c f . \mathrm{Nu}$. 22:28); (3) Israelite readers would explain the evil the snake speaks (his direct contradiction of God's solemn command) by some interference with God's good creation. Hence we have the Jewish interpretative tradition reflected and endorsed in the 
The larger question of whether this is a 'Messianic promise' is also outside the scope of a mere syntactical note. Obviously it all depends on what we mean by a 'Messiah.'22 However, it is worth noting that in Genesis 4:25 the woman calls her son Seth zera' 'ahere ('another seed [descendant]') in place of the one slain.23 That is, she recognises that neither Cain nor Abel could be the 'seed' of 3:15: Cain because of his banishment from the Lord's presence (4:16), and Abel because of his premature death. The author (or final editor) of Genesis develops this line still further, identifying the 'seed' not with Seth, but with a descendant of Seth, by way of Abraham and Judah (49:10). 24

New Testament: Jn. 8:44; Rev. 12:9; 20:2. If this be so (and in view of the place of the story in the structure of Genesis it is hard to believe that only a snake is intended here), then the referent of the second person pronoun would actually be the dark power behind the snake.

22In any event Westermann's position is not really the 'crushing rebuttal' Barr made it out to be (note 5 above): firstly because the woman's 'seed' is not unquestionably collective; and secondly, because the threat is spoken to the snake who has led the humans into disobedience and thus shown itself to be their enemy. In view of such enmity, the defeat of the snake is the rescue of the humans. Hence the idea that it is not possible for a pronouncement of punishment to have a promise contained in it (but what makes it 'impossible'?) overlooks both the fact that the 'promise' for the humans is an implicature of the punishment on the snake, and the relations between the participants.

23It is interesting to note that T.D. Alexander, 'From Adam to Judah: The significance of the family tree in Genesis', EQ 61:1 (1989), 5-19, at 15-17, has argued on literary grounds for an interpretation of zera' here as limited to a specific individual or group. His later article, 'Messianic ideology', seems not to press this, while still favouring a broadly Messianic interpretation.

${ }^{24}$ Alexander, 'Messianic ideology', 32-37 (with bibliography) shows how Gn. 49:8-12 can be taken as 'Messianic'. Some questions related to New Testament usage of these ideas, for which we can only sketch an answer, include the apparent reference to this verse in Rom. 16:20, where it is

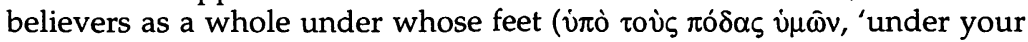

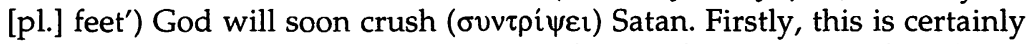
not a direct quote from Gn. 3:15, since the wording there (both Hebrew and LXX) does not match Paul's wording (note that both the Delitzsch Hebrew New Testament and the modern Israeli version wisely make no attempt artificially to bring a verbal allusion to $\mathrm{Gn}$. 3:15 in their rendition of Rom. 16:20). Secondly, if Paul was alluding to this text at all, then within the interpretation offered here, it is through their incorporation 
into Christ that believers participate in his victorious combat (compare Rom. 6:3-10; Col. 2:9-15). In Rev. 12:17 the 'dragon' ( $\delta \rho \alpha ́ \kappa \omega v$, identified in v. 9 with the 'ancient serpent', ò ö $\phi \varsigma$ o o $\alpha \rho \chi \alpha \hat{\imath} \circ \varsigma$, of $\mathrm{Gn} .3$ ), frustrated in its attempt to eat the woman's child and to destroy her, wages war 'with the

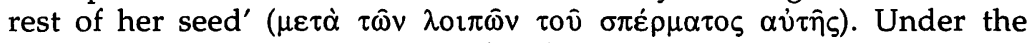
interpretation advanced here, this highly symbolic passage would represent the Messiah (the woman's child) as the (primary) seed, and his followers as 'seed' by virtue of their relation to him. 